doi:10.18575/msrs.sm.e.17.08 UDC 618.33-07(497.6RS) COBISS.RS-ID 6398488

\title{
Analysis of the Results of Amniocentesis Performed at the University Clinical Centre of the Republic of Srpska
}

\begin{abstract}
Introduction: Due to its reliability and relatively low risk, amniocentesis is the most widely used method of prenatal diagnostics, primarily for diagnostics of chromosomal aberrations. Each country has its own specificity in the indications for amniocentesis, and therefore different results.
\end{abstract}

Aim of the Study: The aim of the study was to analyze the results of amniocentesis performed at the University Clinical Centre of the Republic of Srpska by investigating the distributions of indications for amniocentesis, cytogenetic findings and abnormality rate according to indications.

Patients and Methods: The study retrospectively and prospectively analyzed 3994 cases of amniocentesis performed at the University Clinical Centre of the Republic of Srpska between 2009 and 2014. Cytogenetic findings were grouped according to referral indication. The positive predictive value was calculated for each indication.

Results: The most common indications for amniocentesis were advanced maternal age and abnormal screening markers in maternal serum. Overall abnormality rate was $2.35 \%$. The most frequently found chromosomal aberrations were trisomy 21 and balanced reciprocal translocation. The highest positive predictive value had indications parent carrier of chromosomal aberrations and abnormal ultrasound findings. Far from the expected positive predictive value had indications abnormal screening markers in maternal serum and a family history of chromosomal aberrations or congenital anomalies.

Conclusion: Amniocentesis is a feasible tool for detecting fetal chromosomal aberrations and is mostly performed because of advanced maternal age. Analyzing the results of amniocentesis could help us to improve prenatal detection rate of chromosomal aberrations and give us useful database for proper genetic counseling of pregnant women.

Key words: Amniocentesis, indication, chromosomal aberration, positive predictive value.

(Scr Med 2017:48:53-60)

\section{Nina Marić ${ }^{1}$ Snežana Petrović Tepić ${ }^{1}$, Jelica Predojević Samardžić Olivera Ljuboja ${ }^{1}$}

${ }^{1}$ Clinic for Children Diseases, University Clinical Centre of the Republic of Srpska, Banjaluka

\section{Contact address:}

Nina Marić

Street address: Braće Čubrilović $16 a$ $780 o$ o Banja Luka, Republic of Srpska

Bosnia and Herzegovina e-mail:ninamaric.bl@gmail.com phone number: +387-65-610-111

Submitted: January $18^{\text {th }}, 2017$ Accepted: February 24 ${ }^{\text {th }}, 2017$ 


\section{Introduction}

Chromosomal aberrations are changes in the number or structure of chromosomes. They play an important role in human morbidity and mortality., ${ }^{1,2}$ They occur in $4 \%$ of all clinically recognized pregnancies, in half of miscarriages, in $5 \%$ of stillbirths and in $0.5 \%-1 \%$ of live births. ${ }^{3}$ Chromosomal aberrations cause $20 \%-30 \%$ of all infant deaths. The most common prenatally detected chromosomal aberrations are: trisomy 21 (syndrome Down), trisomy 18, trisomy 13, monosomy X and 47, XXY. Other numerical and various structural chromosomal aberrations, balanced and unbalanced, are rare.

The definite diagnosis of chromosomal aberration in the prenatal period is only possible by performing invasive procedures. Because of its reliability and relatively low risk, the most commonly used procedure is amniocentesis, in which a sample of the amniotic fluid is collected using a needle guided by an ultrasound. The sample is then used for cytogenetic analysis, i.e. analysis of fetal chromosomes. Since there is a possibility of fetal loss or other complications associated with amniocentesis (0,3\% - $1,0 \%$ ), it should be performed only in pregnant woman when the risk of a fetal chromosomal aberration is higher than the risk of the procedure. ${ }^{4,5}$

In order to determine this „high risk” group of pregnant women, some screening approaches have been developed during the years. Advanced maternal age was the most common indication for amniocentesis in the past. Penrose has proved the connection between a maternal age and the prevalence of the Down syndrome in $1933 .{ }^{6}$ However, if maternal age over 35 is used as the only indication for amniocentesis, the incidence of Down syndrome will be reduced for less than 20\%. Therefore, during the past forty years, many studies have aimed at developing other methods of screening, using maternal serum markers and ultrasound, as well as increased awareness of risk based on an adverse family and obstetric histories.

Each country has its own specificity in the indications for amniocentesis, and therefore different results. University Clinical Center of the Republic of Srpska is the only institution in our country that performs genetic counseling and prenatal cytogenetic diagnostics. Analyzing the results of amniocentesis could help us to improve prenatal detection rate of chromosomal aberrations by upgrading the screening methods. Also, identification of major epidemiological characteristics of prenatally detected chromosomal aberrations may provide us with valuable information for genetic counseling followed the pregnant woman's decision in electing appropriate testing options.

\section{Aim of the Study}

The aim of the study was to analyze the results of amniocentesis performed at the University Clinical Centre of the Republic of Srpska in the first five years, from January 2009 to January 2014, by investigating the distributions of indications, cytogenetic findings and abnormality rate according to indications.

\section{Patients and Methods}

This study retrospectively and prospectively analyzed 4036 cases of amniocentesis performed at the University Clinical Centre of the Republic of Srpska from January 2009 to January 2014. Clinical data were obtained from records of the genetic counseling. Every woman referred for amniocentesis was initially counseled with a clinical geneticist and signed an informed consent. Amniocentesis was done by trained gynecologist, between 16 and 18 weeks of pregnancy. A sample of the amniotic fluid is collected using a needle guided by an ultrasound. The amniotic fluid cells were in-situ cultured on, at least, two coverslips, harvested by conventional G-banding technique, and then analyzed. In some cases, analysis was completed by the C-banding technique. Some parents were required to analyze lymphocyte karyotype to help judging the origin of abnormal fetal karyotype. Subsequently, 42 specimens were further excluded from this study because of unsuccessful cultivation or contamination with mother cells.

A total of 3994 cytogenetic findings were grouped according to referral indications: advanced maternal age (age 35 years and older), abnormal screening markers in maternal serum, abnormal ultrasound findings, family history of chromosomal aberrations or congenital anomalies, previous fetus/child with chromosomal aberration, parent carrier of chromosomal aberration, history of recurrent abortions or unexplained death in utero and other indications (advanced paternal age, parental diseases, personal reasons, etc.). In cases with multiple indications, the leading one has been taken into account.

All detected chromosomal aberrations, according to ISCN 2009,7 including mosaic cases, have been classified into the following categories: numerical autosomal chromosomal aberrations, numerical sex chromosomal aberrations, marker chromosomes, polyploidies, structural balanced and structural unbalanced chromosomal aberrations. Variant chromosomes were considered to be normal.

Positive predictive value (PPV), which represents overall frequency of chromosomal aberrations among groups, was calculated for each indication. Also, frequencies and 
proportions of different categories of aberrations were calculated by referral indications.

Data used for analysis contained no identifiable personal information in order to protect individuals' privacy. Statistical analyses were performed using the statistical package SPSS. The obtained data were expressed as counts and percentages. Differences among groups were evaluated by using chi-square test. A two-tailed $\mathrm{p} \leq \mathrm{0.05}$ was considered to indicate statistical significance.

\section{Results}

The most frequent referral indication for amniocentesis (Table 1) in our study was advanced maternal age (60.7\%), followed by an abnormal screening markers in maternal serum (24.01\%), family history of chromosomal aberrations or congenital anomalies (4.51\%) and abnormal ultrasound findings (4.38\%).

Table 1. Distribution of indications for amniocentesis and their PPV in detection of chromosomal aberrations

\begin{tabular}{|c|c|c|c|c|}
\hline \multirow{2}{*}{ Referral indication } & \multicolumn{2}{|c|}{$\begin{array}{c}\text { Number of amniotic fluid } \\
\text { specimens }\end{array}$} & \multicolumn{2}{|c|}{ Chromosomal aberrations } \\
\hline & $\mathrm{N}$ & $\%$ & $\mathrm{~N}$ & \% (PPV) \\
\hline Advanced maternal age & 2435 & 60.97 & 57 & 2.34 \\
\hline Abnormal screening markers in maternal serum & 959 & 24.01 & 13 & 1.36 \\
\hline $\begin{array}{l}\text { Family history of chromosomal aberration or congenital } \\
\text { anomalies }\end{array}$ & 180 & 4.51 & 1 & 0.55 \\
\hline Abnormal ultrasound findings & 175 & 4.38 & 12 & 6.86 \\
\hline $\begin{array}{l}\text { History of recurrent abortions or unexplained death } \\
\text { in utero }\end{array}$ & 108 & 2.70 & 5 & 4.63 \\
\hline Previous fetus/child with chromosomal aberration & 51 & 1.28 & 0 & 0 \\
\hline Parent carrier of chromosomal aberration & 17 & 0.43 & 6 & 35.29 \\
\hline Other & 69 & 1.73 & 0 & 0 \\
\hline Total & 3994 & 100 & 94 & 2.35 \\
\hline
\end{tabular}

A total of 94 chromosomal aberrations were found among 3994 amniotic fluid specimens, so overall abnormality rate was $2.35 \%$.

Parent carrier of chromosomal aberration showed the highest PPV in prenatal detection of chromosomal aberrations among indications (35.29\%) (Table 1). Abnormal ultrasound findings showed the second highest PPV (6.86\%). There was only one case of chromosomal aberration among those pregnant women who underwent amniocentesis because of family history of chromosomal aberrations or congenital anomalies, so PPV of this indication was $0.55 \%$.

Numerical aberrations were seen in 57 (59.57\%) and structural in 38 cases (40.43\%). The majority of chromosomal abnormalities were numerical autosomal aberrations (39.36\%). Trisomy 21 was the most common abnormality (32.98\%). The second most frequent findings were structural balanced aberrations (24.47\%), with balanced reciprocal translocation accounting for over half of this group (12.77\%) (Table 2).

The most of chromosomal aberrations were found among advanced maternal age group (57/94; 60.4\%), followed by groups with abnormal screening markers in maternal serum $(13 / 94 ; 13.83 \%)$ and abnormal ultrasound findings (12/94; 12.77\%) (Table 1).

The advanced maternal age accounted for over half of the referral indications (60.97\%). There was no significant difference in overall frequency of chromosomal aberrations between this group and the group of younger women who done amniocentesis because of other reasons. Only three categories of chromosomal aberrations had significantly different proportions between these groups: balanced and unbalanced reciprocal translocations had significantly lower proportion $(p=0.011$ and $p=0.030)$ and inversions had significantly higher proportion $(\mathrm{p}=0.049)$ in the advanced maternal age group (Table 3 ). 
Table 2. Frequency of chromosome aberrations

\begin{tabular}{|c|c|c|}
\hline CHROMOSOMAL ABERRATIONS & $\mathrm{N}$ & $\%$ \\
\hline NUMERICAL & 56 & 59.57 \\
\hline Numerical autosomal chromosomal aberrations & 37 & 39.36 \\
\hline Trisomy 21 & 31 & 32.98 \\
\hline Trisomy 18 & 4 & 4.26 \\
\hline Trisomy 13 & 2 & 2.13 \\
\hline Numerical sex chromosomal aberrations & 13 & 13.83 \\
\hline $45, X$ & 3 & 3.19 \\
\hline $45, X / 46, X X$ & 3 & 3.19 \\
\hline $45, X / 46, X Y$ & 1 & 1.06 \\
\hline chi $46, X X / 46, X Y$ & 1 & 1.06 \\
\hline $47, X X X$ & 2 & 2.13 \\
\hline $47, X X Y$ & 3 & 3.19 \\
\hline Marker chromosomes & 5 & 5.32 \\
\hline In all cels & 2 & 2.13 \\
\hline Mosaic & 3 & 3.19 \\
\hline Poliploidy & 1 & 1.06 \\
\hline STRUCTURAL & 38 & 40.43 \\
\hline Structural balanced chromosomal aberrations & 23 & 24.47 \\
\hline Robertsonian translocations & 5 & 5.32 \\
\hline $\operatorname{rob}(\mathrm{DqDq})$ & 2 & 2.13 \\
\hline $\operatorname{rob}(\mathrm{DqGq})$ & 3 & 3.19 \\
\hline Reciprocal translocations & 12 & 12.77 \\
\hline Inversions & 6 & 6.38 \\
\hline Structural unbalanced chromosomal aberrations & 15 & 15.96 \\
\hline Robertsonian translocations & 1 & 1.06 \\
\hline Reciprocal translocations & 3 & 3.19 \\
\hline Deletions & 2 & 2.13 \\
\hline Duplications & 8 & 8.51 \\
\hline Isochromosomes & 1 & 1.06 \\
\hline Total & 94 & 100 \\
\hline
\end{tabular}


Table 3. Comparison of proportion of chromosomal aberrations between the group with indication of advanced maternal age and the group with other indications

\begin{tabular}{|c|c|c|c|c|c|}
\hline \multirow{3}{*}{ CHROMOSOMAL ABERRATIONS } & \multicolumn{4}{|c|}{ Referral indications: } & \multirow{3}{*}{$\mathrm{p}$} \\
\hline & \multicolumn{2}{|c|}{ Advanced maternal age } & \multicolumn{2}{|c|}{ Other } & \\
\hline & $\mathrm{N}$ & $\%$ of $\mathrm{CA}$ & $\mathrm{N}$ & $\%$ of $\mathrm{CA}$ & \\
\hline NUMERICAL & 35 & 61.40 & 21 & 56.76 & 0.813 \\
\hline Numerical autosomal CA & 22 & 38.60 & 15 & 40.54 & 0.850 \\
\hline Trisomy 21 & 21 & 36.84 & 10 & 27.03 & 0.437 \\
\hline Trisomy 18 & 1 & 1.75 & 3 & 8.11 & 0.140 \\
\hline Trisomy 13 & 0 & 0 & 2 & 5.41 & 0.077 \\
\hline Numerical sex CA & 9 & 15.79 & 4 & 10.81 & 0.541 \\
\hline $45, X$ & 2 & 3.51 & 1 & 2.70 & 0.839 \\
\hline $45, X / 46, X X$ & 1 & 1.75 & 2 & 5.41 & 0.326 \\
\hline $45, X / 46, X Y$ & 1 & 1.75 & 0 & 0 & 0.424 \\
\hline chi $46, X X / 46, X Y$ & 0 & 0 & 1 & 2.70 & 0.211 \\
\hline $47, X X X$ & 2 & 3.51 & 0 & 0 & 0.258 \\
\hline $47, X X Y$ & 3 & 5.26 & 0 & 0 & 0.166 \\
\hline Marker chromosomes & 3 & 5.26 & 2 & 5.41 & 0.965 \\
\hline In all cells & 2 & 3.51 & 0 & 0 & 0.258 \\
\hline Mosaic & 1 & 1.75 & 2 & 5.41 & 0.326 \\
\hline Poliploidy $(69, X X X)$ & 1 & 1.75 & 0 & 0 & 0.424 \\
\hline STRUCTURAL & 22 & 38.60 & 16 & 43.24 & 0.697 \\
\hline Structural balanced CA & 13 & 22.81 & 10 & 27.03 & 0.661 \\
\hline Robertsonian transl. & 4 & 7.01 & 1 & 2.70 & 0.383 \\
\hline Reciprocal transl. & 3 & 5.26 & 9 & 24.32 & 0.011 \\
\hline Inversions & 6 & 10.53 & 0 & 0 & 0.049 \\
\hline Structural unbalanced CA & 9 & 15.79 & 6 & 16.22 & 0.939 \\
\hline Robertsonian transl. & 0 & 0 & 1 & 2.70 & 0.211 \\
\hline Reciprocal transl. & 0 & 0 & 3 & 8.11 & 0.030 \\
\hline Deletions & 2 & 3.51 & 0 & 0 & 0.258 \\
\hline Duplications & 7 & 12.28 & 1 & 2.70 & 0.124 \\
\hline Isochromosomes & 0 & 0 & 1 & 2.70 & 0.211 \\
\hline Total & 57 & 100 & 37 & 100 & 0.949 \\
\hline
\end{tabular}

$C A=$ chromosomal aberration $(s)$ 
Numerical autosomal aberrations and sex chromosomal aberrations were the most frequently identified when the indication was abnormal ultrasound findings, followed by advanced maternal age and abnormal screening markers in maternal serum (Table 4).

Table 4. The frequency and the proportion of chromosomal aberrations by referral indications

\begin{tabular}{|c|c|c|c|c|c|c|}
\hline Indication & $\begin{array}{c}\text { Numerical } \\
\text { autosomal } \\
\text { CA }\end{array}$ & $\begin{array}{c}\text { Numerical sex } \\
\text { CA }\end{array}$ & $\begin{array}{l}\text { Marker } \\
\text { chromoso- } \\
\text { mes }\end{array}$ & Poliploidy & $\begin{array}{l}\text { Structural } \\
\text { balanced CA }\end{array}$ & $\begin{array}{c}\text { Structural } \\
\text { unbalanced } \\
\text { CA }\end{array}$ \\
\hline \multirow[t]{2}{*}{ Advanced maternal age } & $0.90 \%$ & $0.37 \%$ & $0.12 \%$ & $0.04 \%$ & $0.53 \%$ & $0.37 \%$ \\
\hline & $22 / 2435$ & 9/2435 & $3 / 2435$ & $1 / 2435$ & $13 / 2435$ & 9/2435 \\
\hline \multirow{2}{*}{$\begin{array}{l}\text { Abnormal screening markers in } \\
\text { maternal serum }\end{array}$} & $0.73 \%$ & $0.20 \%$ & $0 \%$ & $0 \%$ & $0.21 \%$ & $0.21 \%$ \\
\hline & $7 / 959$ & 2/959 & 0/959 & 0/959 & 2/959 & 2/959 \\
\hline \multirow[t]{2}{*}{ Abnormal ultrasound findings } & $4.57 \%$ & $1.14 \%$ & $0.57 \%$ & $0 \%$ & $0 \%$ & $0.57 \%$ \\
\hline & $8 / 175$ & $2 / 175$ & $1 / 175$ & $0 / 175$ & $0 / 175$ & $1 / 175$ \\
\hline \multirow{2}{*}{$\begin{array}{l}\text { Family history of CA or congenital } \\
\text { anomalies }\end{array}$} & $0 \%$ & $0 \%$ & $0 \%$ & $0 \%$ & $0 \%$ & $0.56 \%$ \\
\hline & $0 / 180$ & 0/180 & $0 / 180$ & $0 / 180$ & $0 / 180$ & $1 / 180$ \\
\hline \multirow[t]{2}{*}{ Previous fetus/child with CA } & $0 \%$ & $0 \%$ & $0 \%$ & $0 \%$ & $0 \%$ & $0 \%$ \\
\hline & $0 / 51$ & $0 / 51$ & $0 / 51$ & $0 / 51$ & $0 / 51$ & $0 / 51$ \\
\hline \multirow[t]{2}{*}{ Parent carrier of CA } & $0 \%$ & $0 \%$ & $0 \%$ & $0 \%$ & $29.41 \%$ & $5.88 \%$ \\
\hline & 0/17 & $0 / 17$ & $0 / 17$ & 0/17 & $5 / 17$ & $1 / 17$ \\
\hline \multirow{2}{*}{$\begin{array}{l}\text { History of recurrent abortions or } \\
\text { unexplained death in utero }\end{array}$} & $0 \%$ & $0 \%$ & $0.93 \%$ & $0 \%$ & $2.78 \%$ & $0.93 \%$ \\
\hline & 0/108 & 0/108 & $1 / 108$ & 0/108 & $3 / 108$ & $1 / 108$ \\
\hline \multirow[t]{2}{*}{ Other } & $0 \%$ & $0 \%$ & $0 \%$ & $0 \%$ & $0 \%$ & $0 \%$ \\
\hline & 0/69 & 0/69 & 0/69 & 0/69 & 0/69 & 0/69 \\
\hline
\end{tabular}

$C A=$ chromosomal aberration(s)

Therefore, these indications had the highest PPV in detection numerical chromosomal aberrations. On the other hand, structural, both balanced and unbalanced, chromosomal aberrations were the most frequently identified when the parent was carrier of chromosomal aberration, followed by history of recurrent abortions or unexplained death in utero (Table 4).

\section{Discussion}

The most frequent referral indication for amniocentesis performed in University Clinical Center of the Republic of Srpska between January 2009 and January 2014 was advanced maternal age. This indication had $60.97 \%$ of pregnant women. This result is similar to result in the report of Milošević Đerić et al. (63\%) and smaller than results of the other studies from region $(78 \%-80 \%) .^{8-}$

${ }^{10}$ In contrast, in countries in which prenatal screening policy is adopted, the proportion of this indication was even smaller ( $18 \%$ and $45 \%) .9,10$ This is due to the fact that most developed countries have national guidelines that recommend fetal aneuploidy screening prior to invasive testing. In the Republic of Srpska, however, fetal aneuploidy screening using a screening ultrasound and markers in maternal serum hadn't been routinely offered to pregnant women before 2012.

A total of 94 chromosomal aberrations were found among 3994 amniotic fluid specimens, so overall abnormality rate was $2.35 \%$ which was similar to that reported in previous studies in other countries $(1.67 \%-3 \%))^{7-10,12-}$ ${ }^{17}$ However, it varied by indication. The highest PPV in detection of chromosomal aberrations had indication parent carrier of chromosomal aberration (35.29\%). Women with this indication have the highest risk of getting a child with unbalanced karyotype. Abnormal 
ultrasound findings showed the second highest PPV (6.86\%) which was similar to that reported in other studies (5.9\% and $11.8 \%){ }^{10,12}$ This indication had the highest PPV in detection numerical autosomal $(4,57 \%)$ and sex chromosomal aberrations (1.14\%). PPV of indication advanced maternal age was $2.34 \%$ which was similar to that reported in other studies $(2.3 \%-4.5 \%) .{ }^{9,10,12,18}$ This indication had the highest PPV in detection numerical autosomal aberrations (0.90\%).

PPV of indication abnormal screening markers in maternal serum was $1.36 \%$, which was similar to that in studies in region (1.40\% and $1.60 \%),{ }^{8,9}$ but was significantly smaller to that reported in countries with long history of prenatal screening (2.60\% and 3.50\%). ${ }^{12,13}$

Indication family history of chromosomal aberrations or congenital anomalies had very small PPV in prenatal detection of chromosomal aberrations in our study (0.55\%). Other studies have reported significantly higher PPV of this indication (1. $0 \%$ and $3.70 \%) .{ }^{9,10}$ In order to do less amniocentesis among this group of women, we should better investigate family history and recommend fetal aneuploidy screening prior to invasive testing, especially in those women who have a family member with free trisomy 21. In the group with other indications (advanced paternal age, parental diseases, personal reasons, etc.), there were no detected chromosomal aberrations. This result was similar to that reported in other numerous studies. ${ }^{18-20}$

The most frequent abnormal finding was trisomy 21 (32.98\%), followed by balanced reciprocal translocation (12.77\%). There was no significant difference in overall frequency of chromosomal aberrations between the group with indication advanced maternal age and the group with the other indications.

\section{Conclusion}

Amniocentesis is a feasible tool for detecting fetal chromosomal aberrations. It is mostly done because of advanced maternal age and it should be offered to pregnant women over 35. Amniocentesis is particularly useful when a parent is a carrier of chromosomal aberration or when fetal ultrasound is abnormal, because these cases belong to the group with the highest risk.

Analyzing the results of amniocentesis could help us to improve prenatal detection rate of chromosomal aberrations and give us useful database for proper genetic counseling of pregnant women. Our results suggest that we should improve screening method that uses markers in maternal serum and better inform pregnant women who come for other reasons, especially for family history.

\section{References}

1. Jacobs PA, Browne C, Gregson N, et al. Estimates of the frequency of chromosome abnormalities detectable in unselected newborns using moderate levels of banding. J. Med. Genet. 1992;29:103-108.

https://doi.org/10.1136/jmg.29.2.103 PMid:1613759 PMCid:PMC1015848

2. Schinzel A. Human Cytogenetics Database. Oxford University Press. Oxford. 1994.

3. Turnpenny P, Ellard S. Emery's Elements of Medical Genetics. 12th Edition. London: Elsevier - Churchill. 2005.

4. Tabor A, Philip J, Madsen M, Bang J, Obel EB, Nørgaard - Pedersen B. Randomised controlled trial of genetic amniocentesis in 4606 low-risk women. Lancet. 1986;1(8493):1287-93. https://doi.org/10.1016/So140-6736(86)91218-3

5. Crandall BF, Howard J, Lebherz TB, Rubinstein L, Sample WF, Sarti D. Follow - up of 2000 second - trimester amniocentesis. Obstet Gynecol. 1980;56(5):625-8. PMid:7432734

6. Penrose LS. The relative effects of paternal and maternal age in mongolism. $\mathrm{J}$ Genet. 1933;27:219-224. https://doi.org/10.1007/BFo2984413

7. Shaffer LG, Slovak M. L, Campbell LJ, eds. ISCN (2009): An International System for Human Cytogenetic Nomenclature. Basel: Karger. 2009.

8. Milošević Đerić A, Aćimović M, Ristanović B, et al. Incidenca hromozomskih aberacija otkrivenih prenatalno metodom amniocenteze u Opštoj bolnici Užice u periodu 2006-2014. godine. Medicinski glasnik. 2014;19(55):17-26.

9. Bukvic R, Fanelli M, Ginevra G. Justifiability of amniocentesis on the basis of positive findings of triple test, ultrasound scan and advanced maternal age. Acta Medica Academica. 2011;40(1):10-16. https://doi.org/10.5644/ama2006-124.3

10. Brajenović - Milić B, Vraneković J, Petrović O, et al. Prenatalna dijagnostika - naša iskustva. Medicina. 2004;42(41):276-280.

11. Zhang L, Zhang X, Liang M, Ren M. Prenatal cytogenetic diagnosis study of 2782 cases of high-risk pregnant women. Chinese Medical Journal. 2010;123(4):423-430.

12. Evans MI, Henry GP, Miller WA, et al. International, collaborative assessment of 146000 prenatal karyotypes: expected limitations if only chromosome-specific probes and fluorescent in-situ hybridization are used. Human Reproduction. 1999;14(5):1213-1216.

https://doi.org/10.1093/humrep/14.5.1213 PMid:10325263

13. Tseng JJ, Chou MM, Lo FC, Lai HY, Chen MH, Ho ES. Detection of chromosome aberrations in the second trimester using genetic amniocentesis: experience during 1995 - 2004. Taiwan J Obstet Gynecol. 2006;45:39-41. https://doi.org/10.1016/S1028-4559(o9)60188-1

14. Karaoguz MY, Bal F, Yakut T, Ercelen NO, Ergun MA, 
Gokcen $\mathrm{AB}$, et al. Cytogenetic results of amniocentesis materials: incidence of abnormal karyotypes in the Turkish collaborative study. Genet Couns. 2006;17:219-230. PMid:16970041

15. Perić $\mathrm{M}$, Mešanović $\mathrm{S}$, Terzić $\mathrm{R}$, et al. Prenatal cytogenetic research in Tuzla canton in the period 2008-2012. Folia Medica Facultatis medicinae Universitatis Saraeviensis. 2014;49(1):77.

16. Kolarski M, Krstić A, Nikić S, et.al. Prenatal diagnosis aneuploidy principles and cost - benephit analysis at the Brcko district hospital (six - years work results). Medicina danas. 2010;9(4-6):157-166.

17. Neagos D, Cretu R, Sfetea R. C, Bohiltea Lc. The Importance of screening and prenatal diagnosis in the identification of the numerical chromosomal abnormalities. Maedica.
2011;6(3):179-184.

18. MulvihillJJ, McKeen EA, Rosner F, etal. Pregnancy outcome in cancer patients. Experience in a large cooperative group. Cancer. 1987;60:1143-1150.

https://doi.org/10.1002/1097-0142(19870901)60:5<1143::AIDCNCR2820600537>3.0.CO;2-E

19. Sloter E, Nath J, Eskenazi B, Wyrobek J. Effects of male age on the frequencies of germinal and heritable chromosomal abnormalities in humans and rodents. Fertil Steril. 2004;81:925-943.

https://doi.org/10.1016/j.fertnstert.2003.07.043 PMid:15066442

20. Uchida IA, Holunga R, Lawler C. Maternal radiation and chromosome aberrations. Lancet. 1962;2:1045-1049.

\section{Analiza rezultata amniocenteza urađenih $u$ Univerzitetskom kliničkom centru Republike Srpske}

\section{SAŽETAK}

Uvod: Zbog svoje pouzdanosti i relativno malog rizika, amniocenteza je najrasprostranjenija metoda prenatalne dijagnostike, prvenstveno dijagnostike hromozomskih aberacija. Svaka zemlja ima svoje specifičnosti po pitanju indikacija za amniocentezu, a samim tim i različite rezultate.

Cilj rada: Cilj rada je bio analizirati rezultate amniocenteza urađenih na Univerzitetskom kliničkom centru Republike Srpske, kroz prikaz distribucije indikacija za amniocentezu, rezultata citogenetskih analiza i stope detekcije hromozomskih aberacija prema indikacijama.

Ispitanici i metode: Retrospektivno-prospektivnom studijom smo analizirali rezultate 3994 amniocenteze urađene na Univerzitetskom kliničkom centru Republike Srpske između 2009. i 2014. godine. Citogenetski nalazi su podijeljeni u grupe zavisno od indikacije za amniocentezu. Za svaku indikaciju smo izračunali pozitivnu prediktivnu vrijednost.

Rezultati: Najčešće indikacije za amniocentezu su bile starija dob majke i rezultat skrininga na osnovu markera u krvi majke. Patoloških nalaza je bilo 2,35\%. Najčešće hromozomske aberacije su bile trizomija 21 i balansirana recipročna translokacija. Hromozomska aberacija kod roditelja i odstupanje u ultrazvučnom nalazu su bile indikacije sa najvećom pozitivnom prediktivnom vrijednosti. Daleko manju pozitivnu prediktivnu vrijednost od očekivane su imale indikacije: rezultat skrininga na osnovu markera u krvi majke i porodična anamneza o hromozomskim aberacijama ili kongenitalnim anomalijama.

Zaključak: Amniocenteza omogućava uspješnu prenatalnu detekciju hromozomskih aberacija i najčešće se izvodi zbog starije dobi trudnice. Analiza rezultata amniocenteze može nam pomoći da povećamo prenatalnu stopu detekcije hromozomskih aberacija i daje nam korisnu bazu podataka za genetičko savjetovanje trudnica.

Ključne riječi: Amniocenteza, indikacije, hromozomske aberacije, pozitivna prediktivna vrijednost. 